\title{
A talaj mikrobiális biomassza meghatározása kloroform fumigációs módszerrel
}

Régóta ismert, hogy a talajban élő mikroorganizmusok csíraszám alapján történő mennyiségi meghatározása nem ad reális kvantitatív adatot az összes biomasszára vonatkozóan. Ezért számos, a tenyésztés szelektív hatását kiküszöbölő módszert dolgoztak ki az utóbbi évtizedekben, amelyek közül egyszerüségüknél és rutinszerű alkalmazhatóságuknál fogva kiemelkednek a kloroform fumigációs eljárások. Előnyük, hogy a mérések eredményeként közvetlenül a biomassza C-, N- vagy más elem tartalmát kapjuk meg, szemben más biomassza becslő eljárásokkal, melyeknél bonyolult és nehezen kalibrálható átszámítási eljárások szükségesek. Jelen összefoglaló aktualitását az adja, hogy 30 évvel ezelőtt jelent meg a Jenkinson által vezetett rothamstedi kutatócsoport öt cikkből álló sorozata a Soil Biology \& Biochemistry folyóiratban a mikrobiális biomassza kloroform fumigációs módszerrel történő meghatározásáról, illetve 40 éve az ezt megalapozó tanulmány. Azóta több mint ezer tudományos cikkben közöltek eredményeket a kloroform fumigációs módszer alkalmazásával.

\section{A talaj mikrobiális biomasszája és mérési módszerei}

Bár a talajok mikrobiális biomasszája viszonylag kicsi, mégis a talaj szerves anyag egyik legfontosabb frakciójának tekinthető, mivel nagyon gyorsan reagál a talaj fizikai és kémiai állapotában bekövetkező változásokra. JENKINSON (1977) úgy fogalmaz, hogy a mikrobiális biomassza olyan, mint a tü foka, amelyen valamennyi talajba került szerves anyagnak át kell hatolnia. A mikrobiális biomassza fontos szerepet játszik a fö növényi tápelemek (N, P és $\mathrm{S}$ ) átalakulásaiban, beépítési (immobilizációs) és ásványosítási (mineralizációs) folyamatok révén befolyásolja felvehetőségüket (MARTENS, 1985; MERCKX \& MARTIN, 1987; NÉMETH, 1996; KÁTAI et al., 2006).

Mezőgazdasági talajokban a mikrobiális szén $0,1-1,0 \mathrm{~g} \cdot \mathrm{kg}^{-1}$ és rendszerint az összes szerves-szén 1-3\%-át teszi ki. Ez a sejttömeg 100-600 kg nitrogént és 50-300 kg foszfort köt meg egy hektár talajban a felső $30 \mathrm{~cm}$-es rétegben (MARTENS, 1995). A tápanyagok felszabadulása és megkötése a mikroorganizmusok életmenet dinamikájától függ. A talajba került növényi maradványok és a gyökerek által kiválasztott anyagok elősegítik a biomassza növekedését és a tápanyagok megkötését, a mikroorganizmusok pusztulását viszont ezen anyagok felszabadulása követi. A mikrobiális biomassza tápanyagszolgáltató képessége abból adódik, hogy míg a növényekben a $\mathrm{C}: \mathrm{N}$ arány 40 80:1, addig a mikroorganizmusokban ez jóval kisebb, 6-12:1. A mikroorganizmusok foszforból is jóval többet tartalmaznak, mint a növények. A mikrobiális biomasszát számos modell (MCGILL et al., 1981; MOLINA et al., 1983; VAN VEEN et al., 1985; 
JENKINSON, 1990) figyelembe veszi a talaj C- és N-forgalmának tanulmányozásában. A hazai tartamkísérletek talajainak szerves-C dinamikáját és ezen belül a mikrobiális $\mathrm{C}$ jelentőségét, eddig kevesen kutatták (CSITÁRI \& HOFFMAN, 2005; KÁTAI, 2006).

A nehézfém-szennyezés lecsökkentheti a mikrobiális biomasszát a talajban (DumONTET \& MATHuR, 1989; Fliessbach et al., 1994; Szili-KovÁcs et al., 1998; 2006), ezért, az a talajminőség egyik indikátora lehet (BROOKES, 1995).

A talaj-mikroorganizmusok biomasszájának meghatározásához egyszerü és megbízható módszerek szükségesek.

A jelenleg használatos módszerek a következők:

- direkt számolási eljárások, melynek során a mikroorganizmusokat megfestik (Nicholas \& PARKInSON, 1967; Ingham \& Klein, 1984; STAMATiadis et al., 1990) és mikroszkóppal vizsgálják. Baktériumoknál méretük, gombáknál pedig az összes hifahosszúság szerint kiszámítják az összes élő térfogatot és ez alapján biomasszájukat (SCHMIDT \& PAUL, 1973);

- a mikrobiális biomasszában kötött szén mikrobiális felszabadításán alapuló fumigációs--inkubációs (CFI) módszerek (JENKINSON, 1966; JENKINSON \& POWLSON, 1976; SPARLING et al., 1986; DUMONTET \& MARTHUR, 1989);

- extrakciós eljárások, a kloroform fumigációt követően a mikrobiális eredetű $\mathrm{C}$ (VANCE et al., 1987; TATE et al., 1988), N (BROOKES et al., 1985), P (BROOKES et al., 1982; Hedley \& STEWART, 1982), S (SAGGAR et al., 1981; Wu et al., 1994) elemek meghatározása;

- a talajból közvetlenül kivonható ATP (adenozin-trifoszfát) (JENKINSON et al., 1979) vagy az összes adenilát, ATP+ADP+AMP (DYCKMANS et al., 2003) kvantitatív meghatározása;

- a talajból közvetlenül kivonható foszfolipidek zsírsav-metilészterré történő átalakítása és gázkromatográfiás mennyiségi elemzése (FROSTEGÅRD et al., 1991);

- fiziológiai módszerek, amelyeknél a szubsztrátadagolást követő respirációs aktivitást használják fel az aktív anyagcserét folytató biomassza meghatározására (ANDERSON \& DOMSCH, 1978b);

- mikrokalorimetriás módszerrel (SPARLING, 1981; VANDENHOVE et al., 1991) a talajból képződött hőmennyiség mérése alapján becslik a biomasszát.

Egyik módszer sem tökéletes, a kutatási cél, illetve a rendelkezésre álló eszközök szabják meg, hogy melyiket alkalmazzák. Kétségtelen tény, hogy az utóbbi két évtizedben a VANCE és munkatársai (1987) által kidolgozott fumigációs extrakciós módszer terjedt el legjobban, amelyre a Scopus ${ }^{\circledR}$ keresőrendszere szerint több mint 1200 hivatkozás történt. Ezt a módszert hazánkban is alkalmazzák (SzILI-KovÁcs et al., 1998; KÁTAI et al., 2005; CSITÁRI \& HOFFMAN, 2005). A kloroform fumigációs módszerrel az összes (élő aktív, élő inaktív és holt) mikrobiális biomassza tömegét mérhetjük meg.

\section{A fumigációs inkubációs (CFI) módszer}

A talajok fertőtlenítésére régóta használnak fumigáló szereket, például metilbromidot a termesztett növényeket károsító kórokozók ellen.

Ezzel kapcsolatos az a megfigyelés mely szerint (STÖRMER, 1908, cit in. JENKINSON, 1966) a talaj szén-diszulfiddal és rokon vegyületeivel történt fumigálása a következő eredményekkel járt: 1. a toxikus fumigálószer-kezelést követően jelentős mennyiségü 
többlet-N tápanyag szabadult fel, ami segítette a növények növekedését; 2. ez a Ntöbblet a fumigáló szer által elpusztított mikroorganizmusokból származott; 3. a fumigáló-kezelést követően a baktériumok szaporodási sebessége megnőtt, és ezek lebontották az elpusztult mikroorganizmusokat, sejtjeikből felszabadítva a nitrogént.

A korábbi megfigyelések eredményeit felhasználva JENKINSON (1966) három feltevést vizsgált meg: 1. A mikrobiális aktivitást és növekedést a talajokban ismeretlen toxikus anyagok gátolják, vagy a mikrobiális populációk közötti antagonisztikus kölcsönhatások gátló hatása érvényesül. A fumigálás következtében a részleges sterilizálás egy bizonyos ideig feloldja ezt a gátlást. 2 . A talajokban a szerves anyag egy része fizikailag, vagy kémiailag védett a mikrobiális támadással szemben, amelyet a kloroformkezelés megszüntet. 3. A részleges sterilizálás (hevítés, levegőn történő kiszárítás, besugárzás) megnöveli a vízoldható szerves anyagok mennyiségét. JENKINSON (1966) ${ }^{14} \mathrm{C}$ izotópos vizsgálataival bizonyította STÖRMER (1908) feltevését, mely szerint a megnövekedett $\mathrm{CO}_{2}$-termelés az elpusztult mikrobiális biomasszából származik. Így ha összevetjük a fumigált és a kontrolltalajok dekompozíciós szintjeit ugyanabban az időszakban és azonos körülmények között, az eltérésük felhasználható a mikrobiális biomassza indirekt becsléséhez (JENKINSON, 1966), a következő egyenlet szerint:

$$
B=F / k
$$

ahol: $B=$ a talaj biomassza $\mathrm{C}, F=$ a fumigált talajból felszabaduló $\mathrm{CO}_{2}-\mathrm{C}$ és a nem fumigált talajból felszabaduló $\mathrm{CO}_{2}-\mathrm{C}$ különbsége (azonos inkubációs feltételek között, ezt az angol nyelvü irodalomban gyakran „ $\mathrm{CO}_{2}$-flush”-nek nevezik), $k=$ a biomasszának az a frakciója, amely a fumigálást követő hirtelen dekompozíciós felgyorsulás során mineralizálódik (a későbbiekben gyakran $\mathrm{k}_{\mathrm{C}}$-nek jelölték, megkülönböztetésül a biomassza N-nél alkalmazott $\mathrm{k}_{\mathrm{N}}$-töl).

A talajok fumigálásához JENKINSON (1966) javaslatára leggyakrabban kloroformot $\left(\mathrm{CHCl}_{3}, \mathrm{CFI}\right.$ módszer) használnak, mivel a többi fumigáló szer, ill. biocid csak nagyon nehezen távolítható el a talajból a kezelés után, vagy pedig kevésbé kényelmes a felhasználása (JENKINSON \& POWLSON, 1976). A hagyományos CFI módszer használata során mineralizálhatóvá teszik a mikroorganizmusokat kloroformgőzzel való fumigálással, amely tönkreteszi a sejtmembránt és a sejt belső részét hozzáférhetővé teszi azon mikroorganizmusok számára, amelyek túlélték a kezelést, vagy inokulum formájában a talajhoz adtak, továbbá a sejtek autolízise is végbemegy. A kloroformgőzök eltávolítása után, amelyet rendszerint ekszikkátorban történő többszöri vákuumozással segítenek elö, 10 napos inkubáció során a mineralizált $\mathrm{C}$ - és $\mathrm{N}$-mennyiséget a $\mathrm{CO}_{2}$-termelés, ill. az $\mathrm{NH}_{4}-\mathrm{N}$ felszabadulás alapján meghatározzák. Ennek elősegítésére azonos nem fumigált, kis mennyiségű mintával beoltják a fumigálást követően átszellőztetett talajokat, annak érdekében, hogy az eredeti mikrobióta kolonizálja azokat. A k faktort ismert mennyiségü ${ }^{14} \mathrm{C}$-jelzett mikrobiális $\mathrm{C}$ mineralizációs sebességének a mérésével határozták meg, amelynek értéke 0,41-nak adódott 10 napos inkubációt figyelembe véve (VORONEY \& PAUL, 1984).

SHIELDS és munkatársai (1974) szerint viszont a kloroformos fumigáció nemcsak a mikroszervezetek elölésén keresztül hat a dekompozíciós szint emelkedésére, hanem hatással van bizonyos extracelluláris mikrobiális anyagcseretermékekre is, amelyek lebonthatóvá válnak. A kloroformkezelés hatására a talajgombák és baktériumok menynyisége 80-99\%-kal csökken (SHIELDS et al., 1974; LYNCH \& PANTING, 1980; SzILIKOVÁCS \& SzEGI, 1992) vagyis 1-20\%-os túlélési aránnyal lehet számolni. A fumigálás körülményei és az adott talaj fizikai és kémiai tulajdonságai egyaránt befolyásolhatják a 
kloroformkezelés hatékonyságát. Ezen belül azonban az egyes mikrobacsoportok (gombák, Gram-pozitív és Gram-negatív baktériumok) túlélési aránya eltérő lehet (ZELLES et al., 1997). A kloroformkezelés hatására a dehidrogenáz enzimaktivitás nagymértékben lecsökken. Ez az intracelluláris enzim az aktív biomassza indikátora. Ehhez hasonlóan az arginin-deamináz aktivitását is jelentősen csökkenti a kloroform (ALEF \& KLEINER, 1987). Más enzimek viszont, mint a béta-glükozidáz, szacharáz, xilanáz és alkalikus foszfatáz aktivitását a kloroformkezelés alig befolyásolja, mivel ezek az enzimek élő sejteken kívül is megőrzik aktivitásukat. A proteáz-aktivitás viszont megnövekedhet a kloroformkezelés után, mivel a lizált sejtekből enzimek szabadulnak fel (NANNIPIERI et al., 1979). Ezek az eredmények azt jelzik, hogy a hidrolitikus lebontó enzimek múködőképesek maradnak a kloroformos fumigáció után. AMATO és LADD (1988) vizsgálatai is azt mutatják, hogy a kloroformgőzzel kezelt talajok megőrzik proteáz-aktivitásukat, de elvesztik glükózbontó és $\mathrm{NH}_{4}-\mathrm{N}$ immobilizáló képességüket. Megállapították továbbá, hogy a 10 napos kloroformkezelés hatására a jelölt sejtek dekompozíciós termékei ninhidrinnel reakcióba lépő vegyületek, föleg aminosavak, részben pedig $\mathrm{NH}_{4}-\mathrm{N}$. Egy napig tartó fumigációt követő 10-napos aerob inkubálás után viszont az összes ninhidrin-reaktiv nitrogén $\mathrm{NH}_{4}-\mathrm{N}$ volt. A fumigálás után felszabaduló ninhidrin-reaktív nitrogén is megbízható eredményt ad a talaj biomassza $\mathrm{C}$ becslésére.

A CFI módszer alkalmazása során két alapfeltevésnek kell teljesülnie: 1. a $\mathrm{CO}_{2}$ mennyiségének, amely a fumigálás során elpusztult mikroorganizmusok mineralizációja során képződik, sokkal nagyobbnak kell lennie annál, mint ami a nem fumigált kontrolltalajban képződik azonos időszak alatt; 2. azonos mennyiségü $\mathrm{CO}_{2}$-nak kell képződnie a nem élö szerves anyagból a fumigált és kontrolltalajban egyaránt. Az első feltétel teljesüléséhez a talaj nedvesítése és legalább 10 napon keresztül történő elöinkubáció szükséges. A második feltétel akkor jelenthet problémát, ha nagyobb mennyiségü növényi maradvány vagy istállótrágya került a talajba röviddel a mintavétel előtt. Ebben az esetben túlságosan alacsony, esetleg negatív biomassza eredmény adódhat, mivel a nem mikrobiális eredetü szerves anyag intenzív mineralizációja elfedheti a mikrobiális eredetüét (MARTENS, 1985). Kísérletileg MARTENS (1985) azt is kimutatta, hogy 28 nappal a gyökerek talajba keverése után ez a probléma már megszünt. Ezért a CFI módszer alapján történő biomassza becslés alkalmazásakor a növényi maradványokat a talajmintából gondosan el kell távolítani és 3 hetes előinkubációs időszak javasolt. A friss szerves anyaggal kapcsolatos probléma áthidalására CHAUSSOD és NICOLARDOT (1982) azt javasolták, hogy a fumigált minták 10-20 nap közötti inkubációja alatt képződött $\mathrm{CO}_{2}$-ot tekintsék kontrollnak. VORONEY és PAUL (1984), valamint FRANZLUEBBERS és munkatársai (1999) vizsgálatai szerint a nemfumigált kontrollt figyelmen kívül lehet hagyni, és elegendő a fumigált mintából mért $\mathrm{CO}_{2}$-képződésből számítani a biomassza C-t. SHEN és munkatársai (1987) szerint viszont csak a megfelelően hosszú előinkubáció, valamint a fumigált és a nem fumigált talajból 0-10 nap között mért $\mathrm{CO}_{2}$ ad megfelelö eredményt.

A következő probléma a $\mathrm{pH}<5$ talajoknál jelentkezett (WILLIAMS \& SPARLING, 1984; COÛTEAUX et al., 1989), ugyanis kis pH esetén az elpusztult mikroorganizmusok mineralizációja lassan ment végbe, ezért az általánosan használt $\mathrm{K}_{\mathrm{C}}$ faktor téves eredményt adott.

ALEF (1993) kritikai megjegyzése a CFI módszerrel kapcsolatban a következő volt: a kloroform nem pusztítja el az összes mikroorganizmust a talajban; más módszerekkel kapott biomassza becslések nem felelnek meg a CFI módszerrel kapott eredményeknek; 
a fumigálás hatására a talaj humuszfrakciójának egy része könnyebben lebonthatóvá válik; és végül a $\mathrm{K}_{\mathrm{C}}$ faktor függ a mikrobiális populáció összetételétől és a pH-tól is.

A CFI módszerrel kapcsolatos problémák miatt alkalmazása az 1990-es évektől kezdett háttérbe szorulni, és helyét egyre inkább a fumigációs extrakciós módszer vette át, föleg Európában.

\section{A fumigációs extrakciós (CFE) módszer}

JENKINSON (1966) vizsgálatai szerint a kloroformkezelés után nemcsak a $\mathrm{CO}_{2}$ képződés sebessége, hanem a talaj $0,5 \mathrm{M} \mathrm{K}_{2} \mathrm{SO}_{4}$-tal extrahálható szervesanyag-tartalma is megnőtt. Ez alapján VANCE és munkatársai (1987) kidolgozták a mikrobiális biomassza $\mathrm{C}$ becslését a kloroform fumigációt követő extrakciós eljárás alapján. A CFI módszerhez hasonlóan itt is szükséges egy átszámítási tényező, amelyet megkülönböztetésül $\mathrm{k}_{\mathrm{EC}}$-vel, illetve a biomassza $\mathrm{N}$ esetében (BROOKES et al., 1985) $\mathrm{k}_{\mathrm{EN}}$-nek jelölnek a szakirodalomban. A biomassza $\mathrm{C}$ számításánál a $\mathrm{k}_{\mathrm{EC}}$-érték 0,38-nak adódott, a fumigációs inkubációs módszerrel történő regresszió számítás alapján (VANCE et al., 1987). A $\mathrm{k}_{\mathrm{EC}}$ faktor megbízhatóságát sokan vizsgálták a mikrobiális biomassza in situ ${ }^{14}$ C-glükóz jelzéses technikájával (SPARLING et al., 1990; CoÛTEAUX et al., 1990; BREMER \& VAN KESSEL, 1990; DiCTOR et al., 1998).

A kálium-szulfáttal extrahálható szerves-C-tartalmat hagyományosan tömény kénsavas foszforsavas $(2: 1)$ kálium-bikromátos oxidációval, majd Mohr-sóoldattal történő redox visszatitrálással állapítják meg. Bár a CFE módszer hamarabb ad eredményt, mint a CFI, valójában jóval munkaigényesebb, különösen a savas roncsolás miatt.

Újabban egyre jobban terjed az automata TOC (total organic carbon) analizátorok használata, melyek vagy a Dumas-féle katalizátoros égetéses eljáráson $\left(680{ }^{\circ} \mathrm{C}\right)$, vagy az UV-perszulfátos oxidáción alapulnak. A fumigációs extrakciós módszer előnye a fumigációs inkubációs módszerrel szemben az, hogy nem kell kivárni a 10 napos inkubációt, hanem a fumigációt követően azonnal lehet mérni, továbbá a savas (VANCE et al., 1987), könnyen lebomló szerves anyagokat nagy mennyiségben tartalmazó (SPARLING et al., 1990; SCHOLLE et al., 1992), vízzel átitatott (INUBUSHI et al., 1991) és gyökerekkel átszőtt (MUELLER et al., 1992) talajok esetén is alkalmazható. Ugyanakkor Ross (1988) és COÛTEAUX és munkatársai (1990) szerint a módszer nem alkalmas a biomassza meghatározáshoz nedves, nagy szerves anyag-tartalmú talajoknál, mivel a kloroform kismértékű vízoldékonysága miatt hatását nem fejti ki megfelelően.

Míg savas talajoknál a biomassza C meghatározása CFI módszerrel problematikus, addig a biomassza $\mathrm{N}$ a CFI és CFE módszerrel egyaránt jól megegyező eredményt adott (AMATO \& LADD, 1994).

Újabban HANEY és munkatársai (2001) a CFI módszert - a nem fumigált kontroll nélkül számítva a biomasszát - jóval megbízhatóbbnak találta, mint a CFE módszert, mert az utóbbinál a talaj $\mathrm{pH}$ és a kálium-szulfát oldat kölcsönhatása miatt a biomasszaeredetű $\mathrm{C}$ kivonhatósága eltérő lehet. 


\title{
A „k" faktor meghatározása a biomassza becslésben
}

\author{
Fumigációs inkubációs módszer $\left(k_{C}\right.$ és $\left.k_{N}\right)$
}

A Jenkinson-féle egyenlet „,k” értéke függ a mikrobiális tényezőktől (pl. faj, növekedési fázis, tápanyagellátás), ill. környezeti tényezőktől (hőmérséklet, pH, talajnedvesség). Mivel a CFI módszer szerint (JENKInSON, 1966; JENKINSON \& POWLSON, 1976) a kloroformos fumigációt követő hirtelen mineralizációs szintemelkedés a frissen elölt mikrobiális biomassza részleges ásványosodásának tulajdonítható, ezért a „,k” tényező meghatározásához olyan mikrobiális anyagot kell felhasználni, amely a növekedés lineáris kezdeti állapotában van (ANDERSON \& DOMSCH, 1978a).

JENKINSON és POWLSON (1976) több mikrobafaj vizsgálatával a „k” faktor értékét 0,5-nek állapította meg $\left(25^{\circ} \mathrm{C}\right.$-on). ANDERSON és DOMSCH (1978a) szerint a k-értékhez a gombák 32,8\%-ban, a baktériumok pedig 8,3\%-ban járultak hozzá, és ez alapján a $\mathrm{k}=$ 0,411 érték használatát javasolták. Ezek a vizsgálatok ellentmondanak JENKINSON és POWLSON (1976) eredményeinek, akik a baktérium- és a gombasejtek hasonló dekompozícióját tapasztalták az inkubáció során. ANDERSON és DOMSCH (1978a) vizsgálataiban a gombák és baktériumok átlagos mineralizálódása között statisztikailag igazolt szignifikáns eltérés mutatkozott. VORONEY és PAUL (1984) a biomassza C becsléséhez ${ }^{14} \mathrm{C}$ jelzéses vizsgálataik alapján $\mathrm{k}_{\mathrm{C}}=0,41$ érték figyelembevételét javasolták.

JENKINSON és POWLSON (1976) a mineralizált bakteriális $\mathrm{N}$ arányát $\left(\mathrm{k}_{\mathrm{N}}\right) \quad 0,45-0,59$ közötti értéknek határozták meg. AMATO és LADD (1988) két baktériumfaj alapján $\mathrm{k}_{\mathrm{N}}=$ 0,46 , két gombafajnál $\mathrm{k}_{\mathrm{N}}=0,28$ értéket állapított meg. VORONEY és PAUL (1984) a biomassza N számolásánál felhívják a figyelmet a fumigált talajok $\mathrm{C}: \mathrm{N}$ arányainak eltéréseire, így pl. 6:1 C:N aránynál $\mathrm{k}_{\mathrm{N}}=0,3$ értéket, 13:1 C:N aránynál pedig $\mathrm{k}_{\mathrm{N}}=0,20$ értéket tartanak használhatónak. AMATO és LADD (1988) fő problémaként azt hangsúlyozták, hogy a biomassza számításához használt egyenletek alkalmazói a sejtbeli C- és Nmennyiségnek csak a $\mathrm{CO}_{2}$-dá és $\mathrm{NH}_{4}-\mathrm{N}$-né alakult arányaira és a megfelelö kontrollértékek megválasztására vannak tekintettel.

A CFI módszernél leggyakrabban alkalmazott $22{ }^{\circ} \mathrm{C}$-os inkubációs hőmérsékleten a $\mathrm{k}_{\mathrm{C}}$ értéke 0,41 (ANDERSON \& DOMSCH, 1978b; MARTENS, 1995), $25^{\circ} \mathrm{C}$-on pedig 0,45nek (JENKINSON, 1988) bizonyult.

A talajnedvesség szintén befolyásolja a $\mathrm{k}_{\mathrm{C}}$ értékét (WARDLE \& PARKINSON, 1990), ezért optimális, vagyis a szabadföldi vízkapacitás körüli nedvességérték beállítása javasolt a mérések előtt.

\section{Fumigációs extrakciós módszer ( $k_{E C}$ és $k_{E N}$ )}

VANCE és munkatársai (1987) a 0,5 $\mathrm{M} \mathrm{K}_{2} \mathrm{SO}_{4}$-os kivonószer használata mellett a $\mathrm{k}_{\mathrm{EC}}$ értékét 0,38-ban állapította meg. SPARLING és WEST (1988) eltérést tapasztalt az ásványi talajok és szerves anyagban gazdag talajok $\mathrm{k}_{\mathrm{EC}}$-értékében, ásványi talajokra 0,33 -at javasolt. Később viszont nem tapasztaltak eltérést e két talajkategória között, és ${ }^{14} \mathrm{C}$ izotópos vizsgálat eredménye alapján $\mathrm{k}_{\mathrm{EC}}=0,42$-öt állapítottak meg (SPARLING et al., 1990). A TOC készülékekkel általában 20\%-kal több szerves-C-tartalmat mérnek, mint a savas dikromátos oxidációval, mivel ez utóbbinak gyengébb az oxidációs hatásfoka (WU et al., 1990), ezért a $\mathrm{k}_{\mathrm{EC}}$ javasolt értéke 0,45-re módosul. JOERGENSEN (1996a) saját és szakirodalmi adatokban szereplö összesen 153 talaj alapján TOC analizátorok használata esetén 0,45 -öt, a hagyományos dikromátos oxidáció esetén 0,38 -at javasol a 
$\mathrm{k}_{\mathrm{EC}}$-értéknek. A $\mathrm{k}_{\mathrm{EC}}$ értéke átlagosan a szántóföldi talajoknál 0,42 , réti jellegü talajoknál 0,49, míg erdei talajoknál 0,51-nek adódott.

BROOKES és munkatársai (1985) a mikrobiális biomassza N meghatározásához a fumigációt követően meghatározott extrahálható $\mathrm{N}$-tartalomban való növekedést javasolták a számításokhoz. A $\mathrm{k}_{\mathrm{EN}}$ értéke vizsgálataik szerint 0,68-nak adódott, továbbá megállapították, hogy a vizsgált talajokban a biomassza $\mathrm{N}$ az összes talaj-N 2-6\%-a közötti tartományban volt. JOERGENSEN és MUELLER (1996) 51 szántóföldi és 23 réti talaj vizsgálata alapján a $\mathrm{k}_{\mathrm{EN}}=0,54$ értéket javasolják általános használatra. Ezzel analóg indirekt becslést ajánlanak a biomassza P (BROOKES et al., 1982; HEDLEY \& STEWART, 1982) és biomassza S (SAGGAR et al., 1981; WU et al., 1994) meghatározásához.

\section{A fumigációs és más módszerek összehasonlítása}

JENKINSON és POWLSON (1976) vizsgálatokat végeztek a fumigációs módszerrel történő közvetett biomassza becslések és a talaj biomassza direkt mikroszkópos mérésének az összehasonlítására. Eredményeik azt mutatják, hogy a kétféle módszer a semleges kémhatású talajok esetében jó egyezéssel használható. Savanyú talajoknál $(\mathrm{pH}<4)$ azonban a direkt módszerrel hétszer nagyobb biomassza C-mennyiséget mértek, mint az indirekt fumigációs módszerrel. Az eltérés fő okaként azt említik, hogy az erősen savanyú talajban az elhalt mikroszervezetek festhető sejtfalai hosszabb ideig maradnak fenn, mint a neutrális talajokban, ami meghamisítja a mikroszkópos mérési módszer eredményeit. A biotérfogat (SCHMIDT \& PAUL, 1973), ill. a biomassza C (sűrüség, víztartalom, C-tartalom figyelembevételével) direkt mérési módszerrel kapcsolatban problémaként említhető, hogy a talaj-mikroorganizmusok mérete és alakja nagyon változatos, emiatt az átlag térfogatuk értéke nem használható fel kielégítően a biomassza becsléséhez (JENKINSON \& POWLSON, 1976). Ezért alakjuk szerint két csoportot szokás megkülönböztetni: gömb és henger alakúakat. Ezeket méret szerint ismét tovább osztályozzák, és osztályonként számolják az élő térfogatot. A fénymikroszkópos direkt biomassza meghatározás és a CFI közötti eltérések okai a következők lehetnek: eltérő festési technikák alkalmazása, az élő és holt mikroorganizmusok megkülönböztetése és az átszámítási faktor, amelyet a mikroorganizmus sejtek méretétől, alakjától függően alkalmaznak a biomassza $C$ becsléshez; végül a vizsgálatot végző személy rutinja is fontos tényező (MARTENS, 1995).

OADES és JENKINSON (1979) szoros korrelációt mutatott ki a mikrobiális biomassza és ATP-tartalom között. 11 talaj vizsgálata alapján a biomassza $\mathrm{C}\left(\mu \mathrm{g} \cdot \mathrm{g}^{-1}\right.$ talaj $)=120 \mu \mathrm{g}$ ATP·g ${ }^{-1}$ talaj, illetve $8,33 \mathrm{mg}$ ATP.g ${ }^{-1}$ biomassza C érték adódott. Ugyanakkor JENKINSON és munkatársai (1979) hideg égövi talajok esetében az előző szerzők adataival megegyezően kimutatták, hogy a talaj ATP-tartalma és a talaj biomassza C aránya viszonylag állandó, és $1 \mu \mathrm{g}$ biomassza C $136 \mu \mathrm{g}$ ATP-vel egyenértékü. SPARLING (1981) ugyanakkor ennek kb. a dupláját mérte. DYCKMANS és munkatársai (2003) az előzőektől eltérő kivonási eljárással, 112 talajminta vizsgálata alapján 3,75 mg ATP, illetve $5,78 \mathrm{mg}$ összes adenilát felel meg $1 \mathrm{~g}$ biomassza C-nek $(\mathrm{r}=0,96)$, továbbá a biomassza $\mathrm{C}\left(\mu \mathrm{g} \cdot \mathrm{g}^{-1}\right.$ talaj $)=68,5 \mu \mathrm{g}$ ATP·g $\mathrm{g}^{-1}$ talajjal volt egyenértékü. Ehhez hasonlóan MARTENS (2001) 4,4 mg ATP·g ${ }^{-1}$ biomassza C-t állapított meg. Az ATP mérés alapján történő 
biomassza becslés azoknál a nagy szervesanyag-tartalmú talajoknál hasznos, amelyeknél a fumigációs módszer nem ad megfelelő eredményt.

A CFI módszerrel meghatározott biomassza C és a ninhidrinnel reagáló $\mathrm{N}$ között szoros összefüggést találtak (AMATO \& LADD, 1988; CARTER, 1991; JANSHAMMERMEISTER, 1996) és ez alapján egy új módszert dolgoztak ki a biomassza C meghatározására a ninhidrinnel történő reakció alapján (AMATO \& LADD, 1994). JOERGENSEN (1996b) 110 talaj vizsgálata alapján a biomassza C és a ninhidrin reaktív N között a következő szignifikáns összefüggést találta:

biomassza $C=22,0 \times E_{\text {nin }}\left(p H>5,0\right.$ talajoknál); biomassza $N=3,1 \times E_{\text {nin }}$ biomassza $C=35,3 \times E_{\text {nin }}\left(p H \leq 5,0\right.$ talajoknál); biomassza $N=5,0 \times E_{\text {nin }}$

ahol: a biomassza $\mathrm{C}\left(\mu \mathrm{g} \mathrm{C} \cdot \mathrm{g}^{-1}\right.$ talaj), az $E_{\text {nin }}=$ ninhidrin reaktív $\mathrm{N}\left(\mu \mathrm{g} \mathrm{N} \cdot \mathrm{g}^{-1}\right.$ talaj); a biomassza $\mathrm{N}$ $\left(\mu \mathrm{g} \cdot \mathrm{g}^{-1}\right.$ talaj) értéke pedig, $\mathrm{C} / \mathrm{N}=7$ feltételezve.

A szubsztrát indukált respiráció és a kloroform fumigációs módszerekkel meghatározott biomassza gyakran szintén szoros korrelációban van (SzILI-KovÁCS \& TöRÖK, 2005). A szubsztrát indukált respirációs módszerek igen eltérő kivitelezése miatt azonban az átszámítási tényező változó, továbbá ez a módszer inkább az ún. aktív biomassza indikátoraként ismert, ezért az összefüggés szorossága a mikrobiális közösség anyagcsere állapotától is függ (SzILI-KovÁCS, 2004).

A mikrokaloriméterrel mért hökibocsátás és a mikrobiális biomassza közötti összefüggés is eléggé szorosnak mutatkozott (SPARLING, 1981; VANDENHOVE et al., 1991).

Az összes kivonható foszfolipid-tartalom és a fumigációs extrakciós módszerrel meghatározott biomassza-tartalom között rendszerint szoros korreláció van (FROSTEGÅRD et al., 1991; BAILEY et al., 2002). FROSTEGÅRD és munkatársainak (1991) vizsgálatai szerint 340 nmol PLFA $1 \mathrm{mg}$ biomassza C-nek feleltethető meg. Erdőtalajoknál az ásványi és szerves horizontból származó mintáknál azonban a CFE és PLFA közötti regressziós együttható értéke szignifikánsan eltérő lehet (LECKIE et al., 2004). A talaj foszfolipid-összetételének vizsgálata elsősorban nem a biomassza, hanem az egyes mikroorganizmus csoportok mennyiségi arányának a megállapítása szempontjából jelentős, melyről HALBRITTER és UZINGER (2005) írt összefoglalót.

Az eddigi szórványos vizsgálatok szerint a talajból kivonható összes DNS-tartalom és a fumigációs extrakciós módszerrel meghatározható biomassza közötti összefüggés nem szignifikáns, ami abból adódhat, hogy a talajokban általában a gombák összmennyisége nagyobb (LECKIE et al., 2004), és DNS-tartalmuk nagyon változó lehet (PAWLOWSKA \& TAYLOR, 2004).

A kloroform fumigációs módszerrel meghatározott mikrobiális biomassza számos talajenzim aktivitásával is szoros korrelációt mutatott, annak ellenére, hogy ezen enzimek jelentős része extracelluláris (KISS, 2003). Így az arilszulfatáz (LI \& SARAH, 2003), az ureáz (KLOSE \& TABATABAI, 1999) és a CFE módszerrel meghatározott mikrobiális biomassza között szoros korrelációt találtak.

\section{A fumigációs módszer biomassza eredményeit befolyásoló tényezők}

Szerves anyag. - Számos vizsgálat bizonyítja, hogy a kloroform fumigációs biomassza mérési eljárás szerves anyagokkal javított, vagy eleve nagy szervesanyagtartalmú talajok esetében sokszor nem használható megfelelő eredménnyel (JENKINSON 
\& Powlson, 1976; Martens, 1985; Joergensen, 1995). SPARLInG és munkatársai (1981) fenolsavakkal kezelt talajoknál csak 28 napig tartó inkubációt követően kapott megfelelő biomassza becslési eredményt, azt megelőzően kis, sőt negatív értékek adódtak. Ezt a jelenséget azzal magyarázták, hogy a fumigált mintákban az újra inokulált populáció nem képes olyan gyorsan lebontani a maradék szubsztrátot, mint a kontroll, fumigálatlan mintákban levő mikroorganizmusok. Valószínűleg ugyanezzel magyarázható LYNCH és PANTING (1980) megfigyelése is, miszerint a talajmintáknak árpagyökerekkel való kezelését követően 18 nappal sem növekedett a biomassza $\mathrm{C}$, bár a hozzáadott C 15\%-a $\mathrm{CO}_{2}$-dá mineralizálódott. MERCKX és MARTIN (1987) hangsúlyozzák, hogy az indirekt mikrobiális biomassza mérések során problémát jelenthet a növényi gyökerek, vagy a friss szerves anyagok jelenléte, mivel ezek a fumigálatlan talajban gyorsabban bomlanak, mint a fumigáltban, így csökkentik vagy meg is szüntethetik a dekompozíciós szint viszonylagos emelkedését. Bizonytalanságokat okozhat a biomaszsza meghatározásában, ha a gyökerekkel sürün átszőtt talajokat a mintavétel után közvetlenül inkubálják (SPARLING et al., 1985; MARTENS, 1985). Ez a probléma a fumigálást követő azonnali extrakcióval elkerülhetö (MERCKX \& MARTIN, 1987; MUELLER et al., 1992).

Az inokulum mérete. - A fumigációs módszerrel kapcsolatban az inokulumméret hatásának tanulmányozása is felmerült. MARTENS (1985) vizsgálatai szerint az inokulumméret befolyása a szerves anyaggal dúsított és kontrolltalajok dekompozíciós szint emelkedésére eltérö. Gyökérmentes talajok tesztelése során megfigyelte, hogy az elhalt mikroorganizmusokból mineralizált $\mathrm{C}$ (k faktor) a fumigált mintákban független az inokulum méretétől. Búzagyökerekkel teli talajmintákkal kísérletezve viszont azt a következtetést vonta le, hogy a szerves anyaggal dúsított, fumigált minták esetében a képződött $\mathrm{CO}_{2}$ mennyiségét az inokulum mérete szignifikánsan befolyásolta, és csak 28 napos inkubációt követően mérhető a többi kísérlethez hasonló érték, miután a gyökerekből való $\mathrm{CO}_{2}$-képződés megszünt. MARTENS (1985) valamint ANDERSON és DOMSCH (1978b) vizsgálatai megerősítették, hogy a biomassza becslést az inokulum mérete nem befolyásolja, ha az elhalt mikroorganizmusokból felszabaduló $\mathrm{CO}_{2}$ mennyiségét a javítóanyag dekompo-zíciója során képződő $\mathrm{CO}_{2}$ értéke nem hamisítja meg. Szerves anyaggal javított talajok esetében a szerves anyag degradációs időszakában tehát a fumigációs inkubációs eljárással történő biomassza meghatározások nem nyújthatnak hiteles eredményeket. A mérés előtti várakozási idő függ a szerves anyag mennyiségétől és minőségétől.

A tárolás körülményei. - A minta tárolási körülményeinek mikrobiális biomasszát befolyásoló szerepéről keveset tudunk (Ross et al., 1980). A szerzők három biomassza mérési módszer esetében vizsgálták a tárolási hőmérséklet hatását a becsült biomassza tömegére. Kimutatták, hogy a talajmintákban a biomassza $\mathrm{C}-20{ }^{\circ} \mathrm{C}$ tárolási hőmérséklet használatakor változott a legkevésbé. Ha ATP-tartalom alapján történt a biomassza meghatározás, szintén ugyanez a tárolási hőfok bizonyult a legmegfelelőbbnek. A mineralizált $\mathrm{N}$ emelkedési szint méréséhez viszont $4{ }^{\circ} \mathrm{C}$ találták a legjobb tárolási hömérsékletnek. A mikrobiális biomassza három eltérő módszerrel történő meghatározásánál egyik tárolási hőfok sem volt egyértelműen jól használható, de általában a rövid periódusokra a $4{ }^{\circ} \mathrm{C}$ mindegyikhez megfelelően alkalmazható volt. Ross (1991) az általa vizsgált talajnál a CFE és CFI biomassza-értékben nem tapasztalt csökkenést 4 ${ }^{\circ} \mathrm{C}$-on 14 hónapig történő tárolás után. STENBERG és munkatársai (1998) 12 különböző 
szántóföldi talajt frissen begyüjtve, valamint $2{ }^{\circ} \mathrm{C}$-on és $-20^{\circ} \mathrm{C}$-on történő 1 napos, 1,3 , 6 és 13 hónapos tárolás után vizsgálták. A CFE módszerrel vizsgált mikrobiális biomassza $2{ }^{\circ} \mathrm{C}$-on, 3 hónapos tárolás után $27 \%$-kal csökkent, de $-20^{\circ} \mathrm{C}$-on történő tárolással nem változott.

A fumigáció időtartama. - Az eredeti módszerleírás 24 órás kloroform fumigálást tartalmaz. A kivonható szerves-C-tartalom a fumigálás időtartamának meghosszabbításával egyes talajoknál - föleg az erdőtalajok humuszos szintjében - növekedhet (Ross \& TATE, 1993; HAUBENSAK et al., 2002). Mások az egynapos fumigációt elegendőnek tartják.

Talajnedvesség. - A mikrobiális biomassza eredményét befolyásolja a minta nedvességtartalma a CFI és CFE módszernél egyaránt. A túl nedves talaj gátolja a kloroform diffúzióját, de a túl száraz talaj sem megfelelő. Ezért általánosságban a minta nedvességtartalmának a beállítása a szabadföldi vízkapacitás, azaz $-0,03 \mathrm{MPa}$ vízpotenciál körüli értékre javasolt, közvetlenül a mérés előtt nedvesítéssel, vagy kíméletes szárítással (ROSS, 1989; SPARLING \& WEST, 1989).

Szürés. - A szüréshez eredetileg Whatman 42, illetve ezzel analóg szürőpapírok használata terjedt el. Mivel a szüröpapírok pórusmérete nem állandó, hanem egy bizonyos tartományban változik, ezért többen a standard pórusméretü $(<0,45 \mu \mathrm{m})$ membránszürőket alkalmazzák (COÛTEAUX et al., 1990), ami a mikroorganizmusokat visszatartja, viszont ez költségesebbé teszi az eljárást. Gyakran a talajminta jellege miatt centrifugálás is indokolt (COÛTEAUX et al., 1990).

Talaj és kivonószer arány. - Az extrakciós eljárások során, különösen az automata analizátorok kapcsán merült fel, a $0,5 \mathrm{M} \mathrm{K}_{2} \mathrm{SO}_{4}$ oldat használatának problematikája. Ez a tömény sóoldat ugyanis kedvezőtlen, károsítja a müszerek egyes alkatrészeit, ezért hígabb oldatok alkalmazása lenne kívánatos. A hígabb oldat használatát az is indokolja, hogy minél töményebb a sóoldat annál kevesebb szerves-C vonható ki a talajokból, elsősorban a proteinek koagulációja miatt (HANEY et al., 2001).

\section{A részleges sterilizálási módszerek összehasonlítása}

A fumigációhoz hasonlóan más biocidkezelés (pl. besugárzás, hőkezelés, vagy szárítás) esetében is megfigyelték, hogy a szervesanyag-lebomlásban rövid ideig tartó gyorsulás következik be (JENKINSON, 1966). Semleges kémhatású talajokban a következő sorrendben növekedett a dekompozíció a kezelések után: légszárítás $<\mathrm{CH}_{3} \mathrm{Br} \leq \mathrm{CHCl}_{3}$ $<$ besugárzás < autoklávozás (POWLSON \& JENKINSON, 1976). A gamma-besugárzás egyes talajokban ugyanúgy befolyásolta a $\mathrm{N}$ mineralizációját és a respirációt, mint a kloroform, ill. a metil-bromid, azonban a mindennapi gyakorlatban ez a kezelés nehezen kivitelezhetö.

A legnagyobb mértékü $\mathrm{O}_{2}$-fogyasztást, $\mathrm{N}$-mineralizációt és $\mathrm{CO}_{2}$-termelést az autoklávozott talajminta beoltását követően mérték (POWLSON \& JENKINSON, 1976), ami összhangban áll azzal a feltevéssel, hogy a hőkezeléssel a jelentős mikrobapusztulás mellett a talaj nem mikrobiális eredetü szervesanyag-frakciójának a lebonthatósága vagy mikrobiális hozzáférhetősége is megnő (JENKINSON, 1966). Az autoklávozás után oldható szerves anyag nagy része biológiailag rezisztens, vagyis a talaj nem mikrobiális 
eredetű frakciójából származik (SALONIUS et al., 1967; POWLSON \& JENKINSON, 1976), ezért az autoklávozás nem alkalmas sem az inkubáción, sem az extrakción alapuló biomassza meghatározásra.

A levegőn való szárítás után kisebb mértékben nő az extrahálható szerves-C, mint más kezeléseknél, ugyanakkor az oldható frakció kevés bomlás rezisztens anyagot tartalmaz, továbbá nem csökken le a talajokban a $\mathrm{C}$ és $\mathrm{N}$ aránya olyan mértékben, mint a többi kezelés hatására (POWLSON \& JENKINSON, 1976). Légszárítást követően a mikrobiális biomassza hozzávetőlegesen 30\%-a pusztul el (VAN GESTEL et al., 1991), ami nem túl kedvező a meghatározás szempontjából. BLAGODATSKIY és munkatársai (1987) a kloroform fumigáció helyett, egyszerüen a talajok $70^{\circ} \mathrm{C}$-on, 24 órán keresztül történő szárítását és újranedvesítésük után a $0,5 \mathrm{M} \mathrm{K}_{2} \mathrm{SO}_{4}$ oldattal kivonható szerves-Ctartalmának mérése alapján javasolták a biomassza $\mathrm{C}$ meghatározását. Ez az eljárás hatékonyabb, mint a légszárítás, de kevésbé hatékony, mint a kloroformkezelés.

A magas hőfokon történő szárításnál jobb eredményt lehet elérni a talajok mikrohullámú kezelésével (ISLAM \& WEIL, 1998) vagy fagyasztva-szárításával (RUMPEL et al., 2001), melyek a kloroformkezelés alternatívájaként szóba jöhetnek és ezáltal egy valóban gyors és biztonságos biomassza meghatározási módszerhez juthatunk.

\section{Összefoglalás}

A talaj mikrobiális biomassza mennyiségének ismerete a növényi tápelemek transzformációja, és a talajállapot minőségének jellemzése miatt fontos. Meghatározását leggyakrabban kloroform fumigációs módszerrel végzik. A kloroformkezelés hatására bekövetkező tömeges mikrobapusztulás arányos az összes biomassza mennyiségével, amely a többlet $\mathrm{CO}_{2}$-képződés, vagy a talajból kivonható megnövekedett szerves anyag alapján mérhető. Tárgyaljuk az inkubációs és extrakciós módszereket, összehasonlítva más eljárásokkal. A méréseket befolyásoló tényezőket és a különböző sterilizálási eljárásokat is összehasonlítjuk.

A dolgozat az OTKA (T 42930 számú pályázat) támogatásával készült.

\section{Irodalom}

AlEF, K., 1993. Estimation of microbial biomass in soil - a critical-view. Zeitschrift für Pflanzenernahrung und Bodenkunde. 156. 109-114.

ALEF, K. \& KLEINER D., 1987. Applicability of arginine ammonification as indicator of microbial activity in different soils. Biology and Fertility of Soils. 5. 141-148.

AмATO, M. \& LADD, J. N., 1988. Assay for microbial biomass based on ninhydin-reactive nitrogen in extracts of fumigated soils. Soil Biology and Biochemistry. 20. 107-114.

AmATO, M. \& LADD, J. N., 1994. Application of the ninhydrin-reactive assay for microbial biomass in acid soils. Soil Biology and Biochemistry. 26. 1109-1115.

Anderson, J. P. E. \& Domsch, K. H., 1978a. Mineralisation of bacteria and fungi in chloroform fumigated soils. Soil Biology and Biochemistry. 10. 207-213.

ANDERSON, J. P. E. \& DOMSCH, K. H., 1978b. A physiological method for the quantitative measurement of microbial biomass in soil. Soil Biology and Biochemistry. 10. 215-221. 
BAILEY, V. L. et al., 2002. Relationships between soil microbial biomass determined by chloroform fumigation-extraction, substrate-induced respiration, and phospholipid fatty acid analysis. Soil Biology and Biochemistry. 34. 1385-1389.

BlagodatskiY, S. A. et al., 1987. Regidratacionnüj metod opredelenija biomasszü mikroorganizmov v pocsve. Pocsvovedenie. 4. 65-71.

Bremer, E. \& VAN Kessel, C., 1990. Extractability of microbial ${ }^{14} \mathrm{C}$ and ${ }^{15} \mathrm{~N}$ following addition of variable rates of labelled glucose and $\left(\mathrm{NH}_{4}\right)_{2} \mathrm{SO}_{4}$ to soil. Soil Biology and Biochemistry. 22. 707-713.

BROOKES, P. C., 1995. The use of microbial parameters in monitoring soil pollution by heavy metals. Biology and Fertility of Soils. 19. 269-279.

BRookes, P. C., Powlson, D. S. \& Jenkinson, D. S., 1982. Measurement of microbial biomass phosphorus in soil. Soil Biology and Biochemistry. 14. 319-329.

BROOKES, P. C. et al., 1985. Chloroform fumigation and the release of soil nitrogen: A rapid direct extraction method to measure microbial biomass nitrogen in soil. Soil Biology and Biochemistry. 17. 837-842.

CARTER, M. R., 1991. Ninhydrin-reactive N released by the fumigation-extraction method as a measure of microbial biomass under field conditions. Soil Biology and Biochemistry. 23. $139-143$.

Chaussod, R. \& NiCOlARDOT, B., 1982. Measurement of microbial biomass in cultivated soils. 1. Kinetic approach and simplified estimation of easily mineralizable carbon. Revue d'Ecologie et de Biologie du Sol. 19. 501-512.

CsitÁRI, G. \& Hoffmann, S., 2005. Comparative study on soil biological parameters at a longterm field experiment. Archives of Agronomy and Soil Science. 51. 563-569.

Coûteaux, M. M., Henkinet, R. \& Bottner, P., 1990. Anomalies in microbial biomass measurements in acid organic soils using extractable carbon following chloroform fumigation. Soil Biology and Biochemistry. 22. 955-957.

CoÛtEAUX, M. M. et al., 1989. Native carbon mineralization of an acid organic soil after use of the chloroform-fumigation method to estimate microbial biomass. Biology and Fertility of Soils. 8. 172-177.

Dictor, M. C., Tessier, L. \& Soulas, G., 1998. Reassessment of the $K_{\text {ec }}$ coefficient of the fumigation-extraction method in a soil profile. Soil Biology and Biochemistry. 30. 119-127.

DuMONTET, S. \& MATHUR, S. P., 1989. Evaluation of respiration-based methods for measuring microbial biomass in metal-contaminated acidic mineral and organic soils. Soil Biology and Biochemistry. 21. 431-436.

DyCKMANS, J. et al., 2003. Adenylates as an estimate of microbial biomass C in different soil groups. Soil Biology and Biochemistry. 35. 1485-1491.

Fliessbach, A., Martens, R. \& Reber, H. H., 1994. Soil microbial biomass and microbial activity in soils treated with heavy metal contaminated sewage-sludge. Soil Biology and Biochemistry. 26. 1201-1205.

FranZluebBers, A. J. et al., 1999. Assessing biological soil quality with chloroform fumigationincubation: why subtract a control? Canadian Journal of Soil Science. 79. 521-528.

Frosteg̊̊Rd, A., Tunlid, A. \& BÅÅth, E., 1991. Microbial biomass measured as total lipid phosphate in soils of different organic content. Journal of Microbiological Methods. 14. 151163.

HALBRitTer A. \& Uzinger N., 2005. A talaj-mikrobióta vizsgálata foszfolipidek alapján. I. Szükségesség és alkalmazási lehetőségek. Agrokémia és Talajtan. 54. 517-534.

HANEY, R. L. et al., 2001. Molar concentration of $\mathrm{K}_{2} \mathrm{SO}_{4}$ and soil $\mathrm{pH}$ affect estimation of extractable $\mathrm{C}$ with chloroform fumigation-extraction. Soil Biology and Biochemistry. 33. $1501-1507$.

Haubensak, K. A., Hart, S. C. \& Stark, J. M., 2002. Influences of chloroform exposure time and soil water content on $\mathrm{C}$ and $\mathrm{N}$ release in forest soils. Soil Biology and Biochemistry. 34. $1549-1562$. 
Hedley, M. J. \& Stewart J. W. B., 1982. Method to measure microbial phosphate in soils. Soil Biology and Biochemistry. 14. 377-385.

Ingham, E. R. \& KleIN, D. A., 1984. Relationships between hyphal activity and staining with fluorescein diacetate. Soil Biology and Biochemistry. 16. 273-278.

Inubushi, K., Brookes, P. C. \& Jenkinson, D. S., 1991. Soil microbial biomass C, N and ninhydrin- $\mathrm{N}$ in aerobic and anaerobic soils measured by the fumigation-extraction method. Soil Biology and Biochemistry. 23. 737-741.

ISLAM, K. R. \& WeIL, R. R., 1998. Microwave irradiation of soil for routine measurement of microbial biomass carbon. Biology and Fertility of Soils. 27. 408-416.

JANS-HAMmERmeister, D. C., 1996. Is there a correlation among factors used to estimate soil microbial biomass? Applied Soil Ecology. 3. 79-83.

Jenkinson, D. S., 1966. Studies on the decomposition of plant material in soil. II. Partial sterilization of soil and the soil biomass. Journal of Soil Science. 17. 280-302.

JENKINSON, D. S., 1977. The soil biomass. NZ Soil News. 25. 213-218.

JENKINSON, D. S., 1988. The determination of microbial biomass carbon and nitrogen in soil. In: Advances in Nitrogen Cycling in Agricultural Ecosystems (Ed.: WILSON, J. R.) 368-386. CAB International. Wallingford.

Jenkinson, D. S., 1990. The turnover of organic carbon and nitrogen in soil. Phil. Trans. R. Soc. Lond. B. 329. 361-368.

Jenkinson, D. S. \& PowLSON, D. S., 1976. The effects of biocidal treatments on metabolism in soil. 5. A method for measuring soil biomass. Soil Biology and Biochemistry. 8. 209-213.

Jenkinson, D. S., Davidson, S. A. \& Powlson, D. S., 1979. Adenosin triphosphate and microbial biomass in soil. Soil Biology and Biochemistry. 8. 167-177.

Joergensen, R. G., 1995. The fumigation extraction method. In: Methods in Applied Soil Microbiology and Biochemistry. (Eds.: ALEF, K. \& NANNIPIERI P.) 376-382. Academic Press. London.

JOERGENSEN, R. G., 1996a. The fumigation-extraction method to estimate soil microbial biomass: calibration of the $k_{E C}$ value. Soil Biology and Biochemistry. 28. 25-31.

JoERGENSEN, R. G., 1996b. Quantification of the microbial biomass by determining ninhydrinreactive N. Soil Biology and Biochemistry. 28. 301-306.

Joergensen, R. G. \& Mueller, T., 1996. The fumigation extraction method to estimate soil microbial biomass: calibration of the $k_{E N}$ value. Soil Biology and Biochemistry. 28. 33-37.

KátAi, J., 2006. Changes in soil characteristics in a mono- and triculture long-term field experiment. Agrokémia és Talajtan. 55. 183-192.

KÁTAI, J., VÁGÓ, I. \& LUKÁCS, V. E., 2005. Relationships between the carbon content and some microbial characteristics in the different soil types. Cereal Research Communications. 33. 389-392.

KÁTAI, J. et al., 2006. Correlation between the nitrogen content of soil and element uptake of maize in a pot experiment. Cereal Research Communications. 34. 215-218.

Kiss I., 2003. Az erodált talajok enzimológiája. Scientia Kiadó. Kolozsvár.

KLOSE, S. \& TABATABAI, M. A., 1999. Urease activity of microbial biomass in soils. Soil Biology and Biochemistry. 31. 205-211.

LECKIE, S. E. et al., 2004. Comparison of chloroform fumigation-extraction, phospholipid fatty acid, and DNA methods to determine microbial biomass in forest humus. Soil Biology and Biochemistry. 36. 529-532.

LI, X. \& SARAH, P., 2003. Arylsulphatase activity of soil microbial biomass along a Mediterranean-arid transect. Soil Biology and Biochemistry. 35. 925-934.

LynCH, J. M. \& PAnting, L. M., 1980. Cultivation and the soil biomass. Soil Biology and Biochemistry. 12. 29-33.

MARTENS, R., 1985. Limitations in the application of the fumigation technique for biomass estimations in amended soils. Soil Biology and Biochemistry. 17. 57-63. 
MARTENS, R., 1995. Current methods for measuring microbial biomass C in soil: Potentials and limitations. Biology and Fertility of Soils. 19. 87-99.

MARTENS, R., 2001. Estimation of ATP in soil: extraction methods and calculation of extraction efficiency. Soil Biology and Biochemistry 33. 973-982.

McGill, W. B. et al., 1981. PHOENIX, a model of the dynamics of carbon and nitrogen in grassland soils. In: Terrestrial Nitrogen Cycles: Processes, Ecosystems, Strategies and Management Impacts. Ecological Bulletin 33. (Eds.: ClARK, F. E. \& RosswaLL, T.) 49-115. Royal Swedish Academy of Sciences. Stockholm.

MerckX, R. \& MARTIN, J. K., 1987. Extraction of microbial biomass components from rhizosphere soils. Soil Biology and Biochemistry. 19. 371-376.

MolinA, J. A. et al., 1983. NCSOIL, a model of nitrogen and carbon transformation in soil: description, calibration and behavior. Soil Sci. Soc. Am. J. 47. 85-91.

Mueller, T., Joergensen, R. G. \& Meyer, B., 1992. Estimation of soil microbial biomass-C in the presence of living roots by fumigation extraction. Soil Biology and Biochemistry. 24. $179-181$.

NANNIPIERI, F. et al., 1979. Changes in aminoacids, enzyme activities and biomass during soil microbial growth. Soil Science. 127. 26-34.

NÉMETH T., 1996. Talajaink szervesanyag-tartalma és nitrogénforgalma. MTA Talajtani és Agrokémiai Kutatóintézet. Budapest.

Nicholas, D. P. \& PARKInSON, D., 1967. A comparison of methods for assessing the amount of fungal mycelium in soil samples. Pedobiologia. 7.23-41.

OADES, J. M. \& JENKINSON, D. S., 1979. Adenosine triphosphate content of the soil microbial biomass. Soil Biology and Biochemistry. 11. 201-204.

PAWLOWSKA, T. E. \& TAYLOR, J. W. 2004. Organization of genetic variation in individuals of arbuscular mycorrhizal fungi. Nature. 427. 733-737.

Powlson, D. S. \& JenKInSON, D. S., 1976. Effects of biocidal treatments on metabolism in soil. 2. Gamma-irradiation, autoclaving, air-drying and fumigation. Soil Biology and Biochemistry. 8. 179-188.

Ross, D. J., 1988. Modifications to the fumigation procedure to measure microbial biomass C in wet soils under pasture: influence on estimates of seasonal fluctuations in the soil biomass. Soil Biology and Biochemistry. 20. 377-383.

Ross, D. J., 1989. Estimation of soil microbial C by a fumigation-extraction procedure: influence of soil moisture content. Soil Biology and Biochemistry. 22. 295-300.

Ross, D. J., 1991. Microbial biomass in a stored soil: a comparison of different estimation procedures. Soil Biol. Biochem. 23. 1005-1007.

Ross, D. J. \& TATE, K. R., 1993. Microbial C and N in litter and soil of a southern beech (Nothofagus) forest: comparison of measurement procedures. Soil Biology and Biochemistry. 25. 467-475.

Ross, D. J. et al., 1980. Influence of storage on soil microbial biomass estimated by 3 biochemical procedures. Soil Biology and Biochemistry. 12. 369-374.

Rumpel, C., Grootes, P. M. \& Kögel-Knabner, I., 2001. Characterization of the microbial biomass in lignite-containing mine soils by radiocarbon measurements. Soil Biology and Biochemistry. 33. 2019-2021.

Saggar, S., Bettany, J. R. \& Stewart, J. W. B., 1981. Measurement of microbial sulfur in soil. Soil Biology and Biochemistry. 13. 493-498.

SAlonius, P. O., RoBinson, J. B. \& ChASE, F. E., 1967. A comparison of autoclaved and gammairradiated soils as media for microbial colonization experiments. Plant and Soil. 27. 239-248.

SCHMidT, E. L. \& PAUL, E. A., 1982. Microscopic methods for soil microorganisms. In: Methods of Soil Analysis. Part 2. Chemical and Microbiological Properties. Agronomy Monograph 9. (Ed.: Page, A. L.) 803-814. American Society for Agronomy. Madison, WI.

Scholle, G., Wolters, V. \& Joergensen, R. G., 1992. Effects of mesofauna exclusion on the microbial biomass in 2 moder profiles. Biology and Fertility of Soils. 12. 253-260. 
Shen, S. M., Brookes, P. C. \& Jenkinson, D. S., 1987. Soil respiration and the measurement of microbial biomass $\mathrm{C}$ by the fumigation technique in fresh and air-dried soil. Soil Biology and Biochemistry. 19. 153-158.

Shields, J. A., PAul, E. A. \& Lowe, W. E., 1974. Factors influencing the stability of labelled microbial materials in soils. Soil Biology and Biochemistry. 6. 31-37.

SPARLING, G. P., 1981. Microcalorimetry and other methods to assess biomass and activity in soil. Soil Biology and Biochemistry. 13. 93-98.

SpARLING, G. P. \& WeST, A. W., 1988. A direct extraction method to estimate soil microbial-Ccalibration in situ using microbial respiration and C-14-labeled cells. Soil Biology and Biochemistry. 20. 337-343.

Sparling, G. P. \& WeSt, A. W., 1989. Importance of water content when estimating soil microbial C, N and P by fumigation-extraction methods. Soil Biology and Biochemistry. 21. $245-253$.

Sparling, G. P., Ord, B. G. \& Vaugham, D., 1981. Changes in microbial biomass and activity in soils amended with phenolic acids. Soil Biology and Biochemistry. 13. 455-460.

Sparling, G. P., Speir, T. W. \& Whale, K. N., 1986. Changes in microbial biomass C, ATP content, soil mono-esterase and phospho-diesterase activity following air drying of soils. Soil Biology and Biochemistry. 18. 363-370.

Sparling, G. P. \& West, A. W. \& Whale, K. N., 1985. Interference from plant roots in the estimation of soil microbial ATP, C, N and P. Soil Biology and Biochemistry. 17. 275-278.

SpARLING, G. P. et al., 1990. Estimation of soil microbial C by a fumigation-extraction method: use on soils of high organic matter content, and a reassessment of the $\mathrm{k}_{\mathrm{ec}}$-factor. Soil Biology and Biochemistry. 22. 301-307.

Stamatiadis, S., Doran, J. W. \& Ingham, E. R., 1990. Use of staining and inhibitors to separate fungal and bacterial activity in soil. Soil Biology and Biochemistry. 22. 81-80.

StenBerG, B. et al., 1998. Microbial biomass and activities in soil as affected by frozen and cold storage. Soil Biol. Biochem. 30. 393-402.

StÖRMER, K., 1908. Über die Wirkung des Schwefelkohlenstoffs und ähnlicher Stoffe auf den Boden. Zentbl. Bakt. II. 20. 282-286.

SziLi-KovÁCs T., 2004. Szubsztrát indukált respiráció a talajban. Agrokémia és Talajtan. 53. $195-214$.

SzILI-KovÁCs T. \& SZEGI J., 1992. Néhány magyarországi talaj mikrobiális biomassza-C tartalmának meghatározása kloroform fumigációs és szubsztrát indukált respirációs módszerrel. Agrokémia és Talajtan. 41. 227-240.

SzILI-KovÁCs T. \& TÖRÖK K., 2005. Szénforráskezelés hatása a talaj mikrobiális aktivitására és biomasszájára felhagyott homoki szántókon. Agrokémia és Talajtan. 54. 149-162.

SzILI-KovÁCs, T. et al., 1998. Soil microbial biomass-C as a possible indicator of soil pollution. Agrokémia és Talajtan. 47. 253-264.

SzILI-KovÁCs, T. et al., 2006. Microbial biomass and phosphomonoesterase activity of the willow (Salix sp.) rhizosphere in a heavy metal polluted soil. Agrokémia és Talajtan. 55. 241-250.

Tate, K. R., Ross, D. J. \& Feltham, C. W., 1988. A direct extraction method to estimate soil microbial-C: Effects of experimental variables and some different calibration procedures. Soil Biology and Biochemistry. 20. 329-335.

VAnCe, E. D., BRookes, P. C. \& Jenkinson, D. S., 1987. An extraction method for measuring soil microbial biomass-C. Soil Biology and Biochemistry. 19. 703-707.

VANDENHOVE, H. et al., 1991. Microcalorimetry as a tool to detect changes in soil microbial biomass. Toxicological and Environmental Chemistry. 30. 201-206.

VAN Gestel, M., LADD, J. N. \& AMATO, M., 1991. Carbon and nitrogen mineralization from two soils of contrasting texture and microaggragate stability: Influence of sequential fumigation, drying and storage. Soil Biology and Biochemistry. 23. 313-322.

VAN VeEN, H. A., LADD, J. N. \& AMATO, M., 1985. Turnover of carbon and nitrogen through the microbial biomass in a sandy loam and a clay soil incubated with $\left[{ }^{14} \mathrm{C}(\mathrm{U})\right]$ glucose and 
$\left[{ }^{15} \mathrm{~N}\right]\left(\mathrm{NH}_{4}\right)_{2} \mathrm{SO}_{4}$ under different moisture regimes. Soil Biology and Biochemistry. 17. $747-$ 756.

Voroney, R. P. \& Paul, E. A., 1984. Determination of KC and kN in situ for calibration of the chloroform fumigation incubation method. Soil Biology and Biochemistry. 16. 9-14.

Wardle, D. A. \& PARKinson, D., 1990. Determination of bacterial and fungal fumigation $\mathrm{k}_{\mathrm{C}}$ factors across a soil moisture gradient. Soil Biology and Biochemistry. 22. 811-816.

Williams, B. L. \& Sparling, G. P., 1984. Extractable N and P in relation to microbial biomass in UK acid organic soils. Plant and Soil. 76. 139-148.

WU, J. et al., 1990. Measurement of soil microbial biomass C by fumigation-extraction - an automated procedure. Soil Biology and Biochemistry. 22. 1167-1169.

WU, J. et al., 1994. Fumigation-extraction method for the measurement of soil microbial biomassS. Soil Biology and Biochemistry. 26. 117-125.

ZELLES, L. et al., 1997. Changes in soil microbial properties and phospholipid fatty acid fractions after chloroform fumigation. Soil Biology and Biochemistry. 29. 1325-1336.

Érkezett: 2006. július 18.

SZILI-KOVÁCS TIBOR és TÓTH JÁNOS ATTILA

MTA Talajtani és Agrokémiai Kutatóintézet, Budapest és Debreceni Egyetem Természettudományi Kar

Ökológia Tanszék, Debrecen

Postai cím: SZILI-KOVÁCS TIBOR, MTA Talajtani és Agrokémiai Kutatóintézet, 1022 Budapest, Herman Ottó út 15.E-mail: szili_k@rissac.hu 